\title{
Role of calcium in the induction of cardiac hypertrophy and myofibrillar disarray Experimental studies of a possible cause of hypertrophic cardiomyopathy
}

\author{
PETER C PEARCE, $†$ CHRISTINE HAWKEY, $\dagger$ CECIL SYMONS, \\ ECKHARDT G J OLSEN* \\ From the ${ }^{\star}$ Department of Histopathology, National Heart and Chest Hospitals, Cardiothoracic Institute; the \\ $\dagger$ Department of Veterinary Science, Institute of Zoology; and the $\ddagger$ Department of Cardiology, Royal Free \\ Hospital, London
}

SUMMARY The role of calcium in the pathogenesis of hypertrophic cardiomyopathy was investigated experimentally. For this purpose the calcium antagonist verapamil and the calcium ionophore A23187 were administered to pregnant rats together with triac in order to observe their effect on triac induced myocardial disarray and hypertrophy in developing rat hearts. At a low dose verapamil reduced both the level of disarray and hypertrophy, but a higher dose produced hypertrophy when given alone. A23187 did not appreciably potentiate the actions of triac when given in combination but when administered alone produced both disarray and hypertrophy. Verapamil prevents the inward movement of calcium ions to the myocardial cell, whereas A23187 increases the inflow of calcium ions. The results suggest that the actions of triac in producing myocardial disarray and hypertrophy are attributable to an increased concentration of intracellular calcium.

Hypertrophic cardiomyopathy, in common with all other cardiomyopathies, is of unknown aetiology. ${ }^{1}$ It has been established that myofibrillar disarray is characteristic of hypertrophic cardiomyopathy, ${ }^{2}$ and it is likely that other cardiac muscle abnormalities, which permit firm morphological diagnosis, ${ }^{3}$ develop subsequently. Quantifiable ultrastructural changes, mimicking those seen in patients with hypertrophic cardiomyopathy, can be produced in the heart muscle of developing rats by administering triiodothyroacetic acid during pregnancy. ${ }^{4}$ This model, which was developed from observations that hypertrophic cardiomyopathy can be associated with covert or overt hyperthyroidism, ${ }^{56}$ has been used to show that the deleterious effect of triac is due to an increase in cell membrane permeability. ${ }^{7}$ This study therefore suggested that an increased entry of calcium into the myocardial cells may be at least

Requests for reprints to Dr EGJ Olsen, Department of Histopathology, National Heart Hospital, Westmoreland Street, London W1M 8BA.

Accepted for publication 2 July 1985 partly responsible for the abnormalities produced.

The calcium antagonist verapamil has been used for the symptomatic treatment of hypertrophic cardiomyopathy, ${ }^{8}$ and some reports have suggested that a reduction in hypertrophy may also take place. ${ }^{9}$ We report the results of experiments in which the rat model was used to study the influence of verapamil on triac induced disarray and hypertrophy. To elucidate further the role of calcium in the pathogenesis of these morphological changes the effects of the ionophore A23187 were also examined.

\section{Materials and methods}

The experimental methods followed those described by Hawkey et al ${ }^{10}$ and Pearce et al. ${ }^{11}$ Virgin Wistar rats were divided into 12 groups of three, mated, and injected daily throughout pregnancy as shown in Table 1. The hearts of randomly selected offspring were analysed histologically and electronmicroscopically at two and seven days after birth. A coding system ensured that the observer had no knowledge of a group from which the samples came. 
Table 1 Drugs and their doses given to 12 groups of rats

\begin{tabular}{lll}
\hline Group & Treatment & Dose \\
\hline 1 & Buffer & $0 \cdot 6 \mathrm{ml}$ \\
2 & Triac & $60 \mu \mathrm{g}$ \\
3 & Triac & $60 \mu \mathrm{g}$ \\
& Verapamil & $1 \mathrm{mg}$ \\
4 & Triac & $60 \mu \mathrm{g}$ \\
& Verapamil & $2 \mathrm{mg}$ \\
5 & Triac & $60 \mu \mathrm{g}$ \\
6 & Verapamil & $4 \mathrm{mg}$ \\
7 & Verapamil & $4 \mathrm{mg}$ \\
8 & Buffer & $0 \cdot 6 \mathrm{ml}$ \\
9 & Triac & $60 \mu \mathrm{g}$ \\
& Triac & $60 \mu \mathrm{g}$ \\
10 & A23187 & $15 \mu \mathrm{g}$ \\
& Triac & $60 \mu \mathrm{g}$ \\
11 & A23187 & $30 \mu \mathrm{g}$ \\
12 & Triac & $60 \mu \mathrm{g}$ \\
\hline
\end{tabular}

DRUGS

Triac (diethanolamine salt of triiodothyroacetic acid, Sigma) was dissolved in glycine buffer, $\mathrm{pH} \mathrm{10,}$ at a concentration of $100 \mu \mathrm{g} / \mathrm{ml}$ in water for injections. Verapamil HCl (Abbott Laboratories) was supplied as a powder and made up to a concentration of $2.5 \mu \mathrm{g} / \mathrm{ml}$ in water for injections. These two solutions were stored in the dark at $4^{\circ} \mathrm{C}$. A23187 calcium ionophore (Calbiochem-Behring) was supplied as
Table 2 Details of pregnancies in rats

\begin{tabular}{llcl}
\hline Group & No pregnant & Mean litter size & $\%$ live births \\
\hline 1 & $2 / 3$ & $11 \cdot 5$ & 100 \\
2 & $1 / 3$ & 9 & 100 \\
3 & $3 / 3$ & $10 \cdot 7$ & 100 \\
4 & $0 / 3$ & - & - \\
5 & $0 / 3$ & 5 & 100 \\
6 & $1 / 3 \star$ & 9 & 100 \\
7 & $2 / 3$ & 12 & 92 \\
8 & $1 / 3$ & 17 & $100 \dagger$ \\
9 & $1 / 3$ & 9 & 100 \\
10 & $1 / 3$ & $7 \cdot 7$ & 85 \\
11 & $3 / 3$ & $10 \cdot 3$ & $94 \ddagger$ \\
12 & $3 / 3$ & & \\
\hline
\end{tabular}

*One additional rat was pregnant but died on day 20.

+ All were born alive but died within 24 hours.

In one litter, eight out of 11 were born alive but died within 24 hours.

the free acid. The powder, $10 \mathrm{mg}$, was dissolved in $1 \mathrm{ml}$ ethanol with the aid of ultrasonic agitation, and this stock solution was stored in the dark at room temperature. For injection (on each day of injection), an aliquot of $50 \mu \mathrm{l}$ was removed and added to $5 \mathrm{ml}$ of rapidly mixing $5 \%$ dextrose. The resulting solution of $100 \mu \mathrm{g} / \mathrm{ml}$ was colloidal but was suitable for injections.

HISTOLOGICAL EXAMINATION

Histological examination was carried out on paraffin

Table 3 Cell diameters of rats at two and seven days after birth

\begin{tabular}{|c|c|c|c|c|c|}
\hline Group & Drug/dose & $\begin{array}{l}\text { Mean cell } \\
\text { diameter }(\mu m)\end{array}$ & $S D$ & p value & pvalue \\
\hline \multicolumn{6}{|c|}{2 days } \\
\hline $\begin{array}{l}1 \\
2 \\
3 \\
6\end{array}$ & $\begin{array}{l}\text { Buffer } \\
\text { Triac } 60 \mu \mathrm{g} \\
\text { Triac } 60 \mu \mathrm{g}+\text { verapamil } 1 \mathrm{mg} \\
\text { Verapamil } 4 \mathrm{mg}\end{array}$ & $\begin{array}{l}7 \cdot 22 \\
8 \cdot 20 \\
7 \cdot 51 \\
8 \cdot 07\end{array}$ & $\begin{array}{l}1 \cdot 06 \\
1 \cdot 11 \\
1 \cdot 07 \\
1 \cdot 22\end{array}$ & $\begin{array}{l}<0.001^{\star} \\
<0.01 \star \\
<0.001^{\star}\end{array}$ & $\begin{array}{l}<0.001 \dagger \\
\text { NSt }\end{array}$ \\
\hline \multicolumn{6}{|c|}{7 days } \\
\hline $\begin{array}{l}1 \\
2 \\
3 \\
6\end{array}$ & $\begin{array}{l}\text { Buffer } \\
\text { Triac } 60 \mu \mathrm{g} \\
\text { Triac } 60 \mu \mathrm{g}+\text { verapamil } 1 \mathrm{mg} \\
\text { Verapamil } 4 \mathrm{mg}\end{array}$ & $\begin{array}{l}8 \cdot 41 \\
9 \cdot 41 \\
8 \cdot 56 \\
8 \cdot 97\end{array}$ & $\begin{array}{l}1 \cdot 12 \\
1 \cdot 38 \\
1.41 \\
1.48\end{array}$ & $\begin{array}{l}<0.001^{\star} \\
\mathrm{NS}^{\star} \\
<0.001^{\star}\end{array}$ & $\begin{array}{l}<0.001 \dagger \\
<0.01 \dagger\end{array}$ \\
\hline \multicolumn{6}{|c|}{2 days } \\
\hline $\begin{array}{r}7 \\
8 \\
10 \\
11 \\
12\end{array}$ & $\begin{array}{l}\text { Buffer } \\
\text { Triac } 60 \mu \mathrm{g} \\
\text { Triac } 60 \mu \mathrm{g}+\mathrm{A} 2318730 \mu \mathrm{g} \\
\text { Triac } 60 \mu \mathrm{g}+\mathrm{A} 2318760 \mu \mathrm{g} \\
\mathrm{A} 2318760 \mu \mathrm{g}\end{array}$ & $\begin{array}{r}8 \cdot 00 \\
9.99 \\
9 \cdot 77 \\
10 \cdot 34 \\
9.53\end{array}$ & $\begin{array}{l}1 \cdot 22 \\
1 \cdot 57 \\
1 \cdot 41 \\
1 \cdot 61 \\
1 \cdot 76\end{array}$ & $\begin{array}{l}<0.001 \ddagger \\
<0.001 \ddagger \\
<0.001 \ddagger \\
<0.001 \ddagger\end{array}$ & $\begin{array}{l}\text { NS\$ } \\
\text { NS\$ } \\
\text { NS\$ }\end{array}$ \\
\hline \multicolumn{6}{|c|}{7 days } \\
\hline $\begin{array}{r}7 \\
8 \\
10 \\
11 \\
12\end{array}$ & $\begin{array}{l}\text { Buffer } \\
\text { Triac } 60 \mu \mathrm{g} \\
\text { Triac } 60 \mu \mathrm{g}+\mathrm{A} 2318730 \mu \mathrm{g} \\
\text { Triac } 60 \mu \mathrm{g}+\mathrm{A} 2318760 \mu \mathrm{g} \\
\text { A23187 } 60 \mu \mathrm{g}\end{array}$ & $\begin{array}{r}8 \cdot 69 \\
9 \cdot 98 \\
10 \cdot 10 \\
10 \cdot 51 \\
10 \cdot 41\end{array}$ & $\begin{array}{l}1.26 \\
1.63 \\
1.41 \\
1.55 \\
1.62\end{array}$ & $\begin{array}{l}<0.001 \ddagger \\
<0.001 \ddagger \\
<0.001 \ddagger \\
<0.001 \ddagger\end{array}$ & $\begin{array}{l}\text { NS\$ } \\
<0.001 \S \\
<0.01 \S\end{array}$ \\
\hline
\end{tabular}

* $v$ group 1.

$+v$ group 2.

$\ddagger v$ group 7.

$\S v$ group 8. 


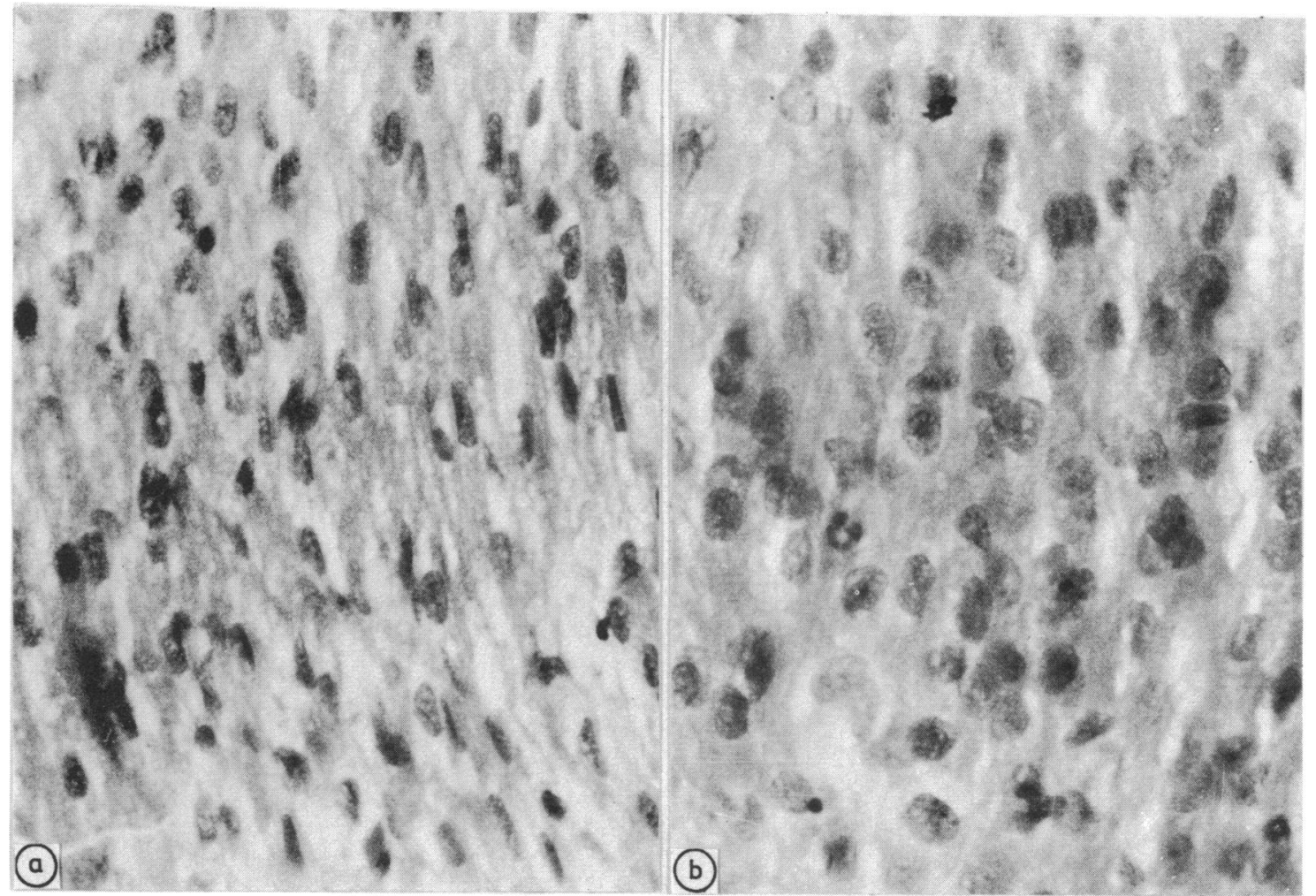

Fig. 1 Photomicrographs of the myocardium of 2 day old rats from (a) group 1 (control) and (b) group 6 (verapamil 4 mg). (Haematoxylin and eosin; original magnification $\times 400$.)

embedded sections stained with haematoxylin and eosin. The diameter of at least 200 cells from each group was measured on a Projectina microscope. These were measured across the point of a nucleus in fibres that were in longitudinal section. The test of comparison of means was used to compare cell diameters from different groups of rats.

\section{ELECTRONMICROSCOPY}

Electronmicroscopy was used to evaluate myofibrillar disarray and hypertrophy. Sections were embedded in epoxy resin.and stained with lead citrate $^{12}$ and uranyl acetate. A score for disarray was given as the total number of foci of disarray and crossover observed in five squares of longitudinally arranged fibres on a 200 mesh grid. The score for hypertrophy was based on the number of mitochondria separating two sarcomeres of adjacent parallel myofibrils: $0-2$ was normal and scored $0 ; 3-5$ scored 1-3.

Table 4 Electronmicroscopy score for disarray in rats at two and seven days after birth

\begin{tabular}{|c|c|c|c|c|c|c|c|c|c|c|}
\hline Group & Drug/dose & $2 d c$ & $y s^{\star}$ & & & & $7 d$ & Lays & & \\
\hline $\begin{array}{r}1 \\
2 \\
3 \\
6 \\
7 \\
8 \\
10 \\
11 \\
12\end{array}$ & $\begin{array}{l}\text { Buffer } \\
\text { Triac } 60 \mu \mathrm{g} \\
\text { Triac } 60 \mu \mathrm{g}+\text { verapamil } 1 \mathrm{mg} \\
\text { Verapamil } 4 \mathrm{mg} \\
\text { Buffer } \\
\text { Triac } 60 \mu \mathrm{g} \\
\text { Triac } 60 \mu \mathrm{g}+\mathrm{A} 2318730 \mu \mathrm{g} \\
\text { Triac } 60 \mu \mathrm{g}+\mathrm{A} 2318760 \mu \mathrm{g} \\
\text { A23187 }\end{array}$ & $\begin{array}{r}1 \\
8 \\
3 \\
1 \\
2 \\
10 \\
16 \\
14 \\
11\end{array}$ & $\begin{array}{r}0 \\
7 \\
3 \\
0 \\
3 \\
9 \\
16 \\
12 \\
16\end{array}$ & $\begin{array}{r}1 \\
9 \\
2 \\
3 \\
3 \\
15 \\
12 \\
13 \\
13\end{array}$ & $\begin{array}{r}2 \\
11 \\
2 \\
2 \\
2 \\
11 \\
8 \\
15 \\
12\end{array}$ & $\begin{array}{ll}0 & \\
1 & 1\end{array}$ & $\begin{array}{l}2 \\
8 \\
1 \\
4 \\
0 \\
7 \\
3 \\
4 \\
1\end{array}$ & $\begin{array}{l}1 \\
4 \\
1 \\
0 \\
0 \\
6 \\
1 \\
7 \\
3\end{array}$ & $\begin{array}{r}2 \\
6 \\
1 \\
0 \\
15 \\
8 \\
11 \\
8\end{array}$ & $\begin{array}{r}1 \\
14 \\
0 \\
1 \\
14 \\
3 \\
9 \\
1\end{array}$ \\
\hline
\end{tabular}

*Scores for individual rats. 


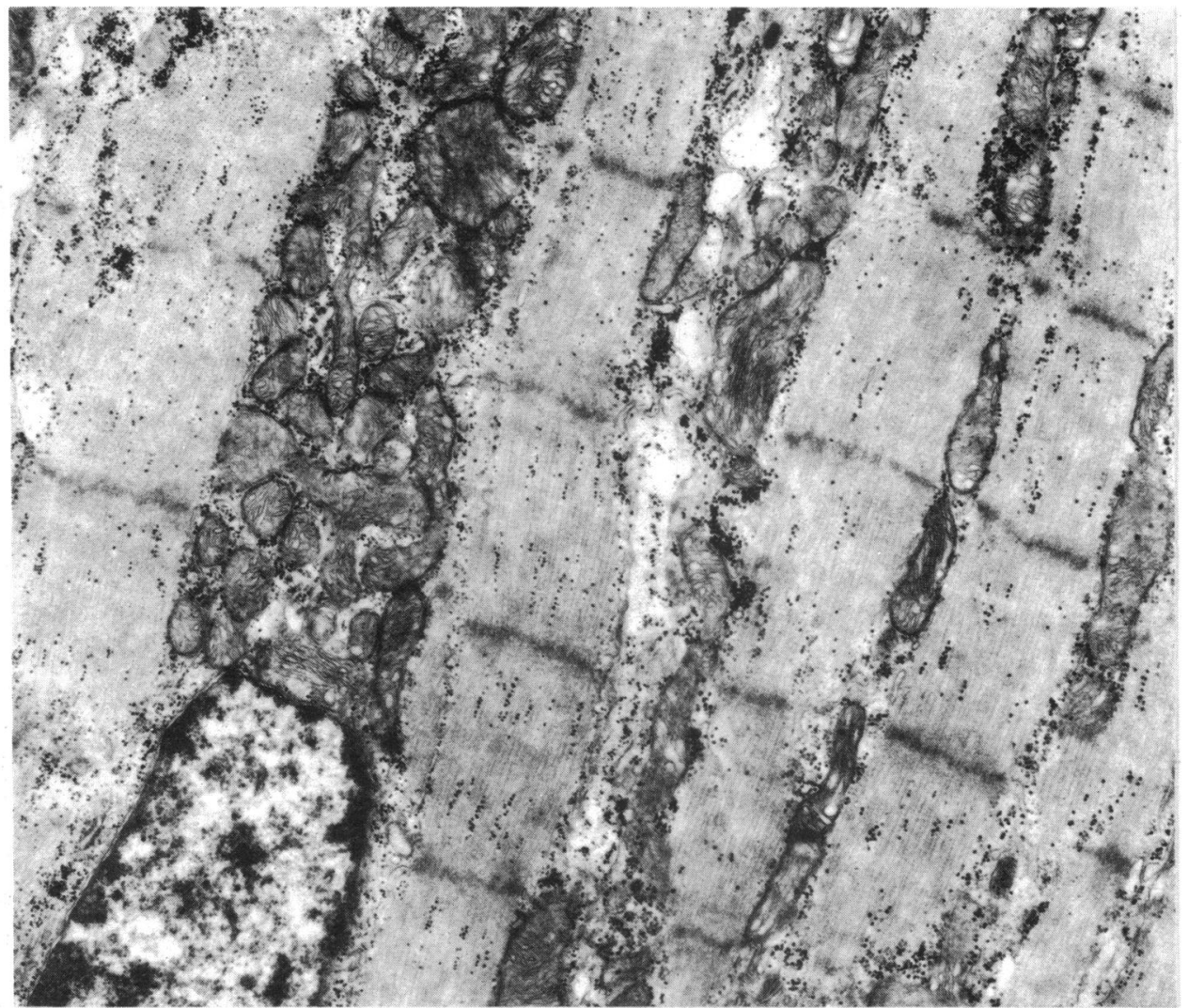

Fig. 2 Electronmicrograph of a 2 day old rat from control group 1 showing regular arrangement of myofibrils. (Lead citrate and uranyl acetate, original magnification $\times 24000$.)

\section{Results}

\section{PREGNANCIES}

Table 2 shows the details of the pregnancies. Abnormalities were noted in all experiments in which verapamil at more than $1 \mathrm{mg}$ per rat was injected. The pregnancy rate was low, and in groups 4 and 5 no rats became pregnant. In group 6 (verapamil $4 \mathrm{mg}$ alone) two rats conceived, but one died very close to term. At post mortem examination two fully grown fetuses were present. No gross abnormalities were found in either of the fetuses or in the mother. The second rat in this group that became pregnant had a smaller litter than normal. In the experiments with A23187 only one rat from group 9 became pregnant, producing a larger than normal litter of 17 offspring, all of which died within 24 hours. All the offspring from one of the rats in group 12 also died within 24 hours of birth.

LIGHT MICROSCOPICAL FINDINGS

The hearts of the two fetuses from the dead mother in group 6 showed signs of autolysis, but no other abnormalities were present. The heart of the dead mother also appeared to be normal.

In both experiments triac increased the cell diameters compared with the buffer control, as previously reported..$^{41011}$ This hypertrophy was significantly reduced, although not totally prevented, by verapamil at $1 \mathrm{mg}$ (Table 3). Verapamil alone, at $4 \mathrm{mg}$, produced a similar degree of hypertrophy to triac alone (Fig. 1). Triac induced hypertrophy was not affected by the concurrent administration of $\mathrm{A} 23187$ except in 7 day old rats that had received A23187 $60 \mu \mathrm{g}$ with triac. In these the degree of hypertrophy was significantly increased (Table 3). A23187 also produced hypertrophy when it was given alone.

ELECTRONMICROSCOPICAL FINDINGS

Table 4 shows the scores for disarray and crossover. Regular arrangement of myofibrils (Fig. 2) predominated in the buffer control groups, although a few foci of disarray were found. The degree of disarray 


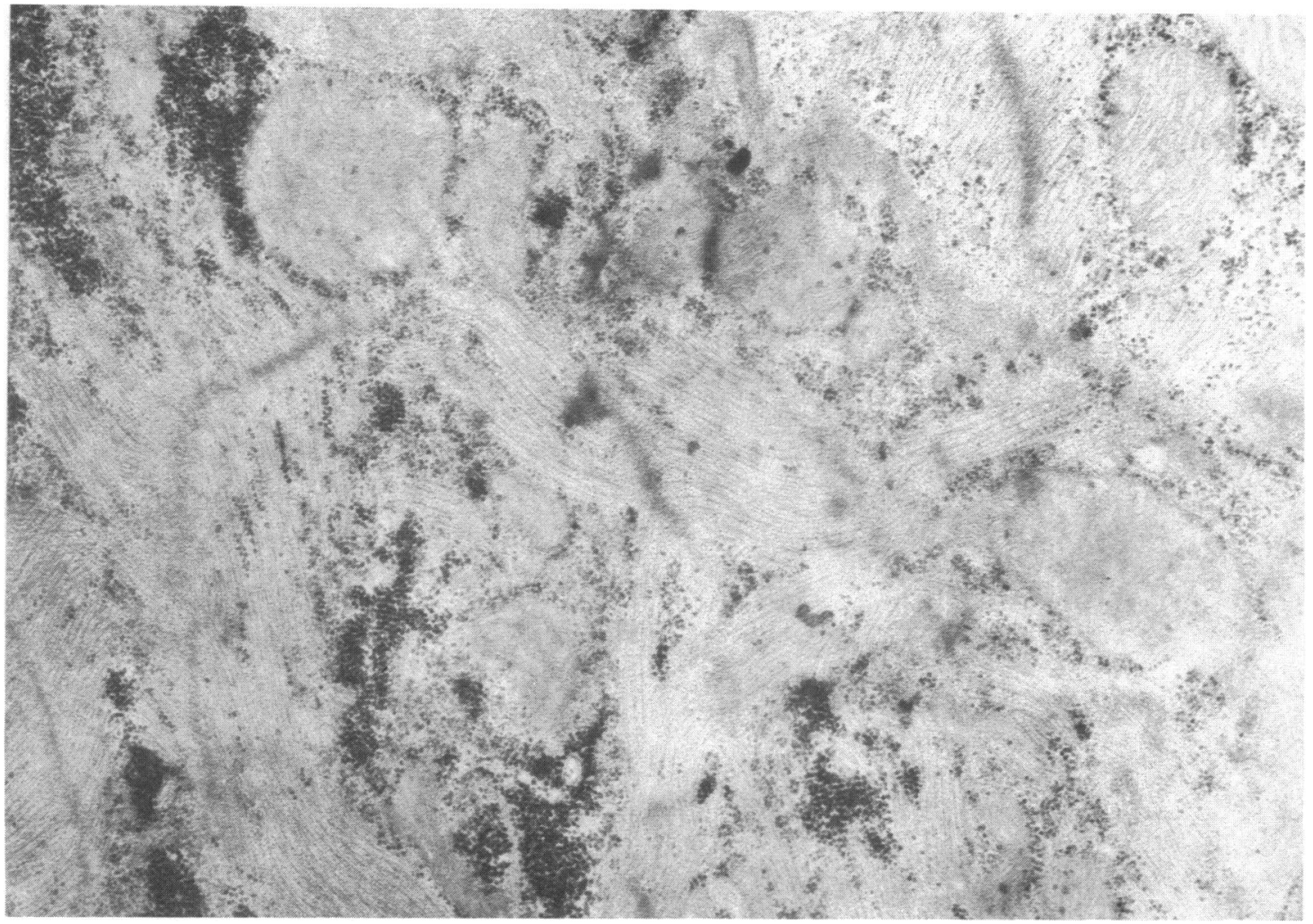

Fig. 3 Electronmicrograph of a 2 day old rat from a triac treated mother (group 2) showing severe disarray of myofibrils and myofilaments. (Lead citrate and uranyl acetate; original magnification $\times 19000$.)

was increased by the administration of triac (Fig. 3). When verapamil ( $1 \mathrm{mg}$ ) was given with triac the level of disarray was reduced to control levels at both two and seven days. Verapamil alone $(4 \mathrm{mg})$ had no effect.

When A23187 was administered with triac the level of disarray was approximately the same as that when triac was given alone. Nevertheless, disarray was also observed when A23187 was given alone, most prominently in the 2 day old rats.

Table 5 shows the scores for hypertrophy. Mild hypertrophy was noted in six out of 17 buffer control rats, but all hearts from the rats treated with traic alone were hypertrophied to the same or to a greater degree. Figure 4 shows an example of hypertrophied myocardium. Concurrent administration of verapamil reduced the level of hypertrophy, but the higher dose, given alone, produced hypertrophy.

When A23187 was administered with triac the hypertrophy was unaltered. In the 2 day old rats A23187 produced hypertrophy when given alone, and two rats at 7 days old from the group treated

Table 5 Electronmicroscopy score for hypertrophy in rats at two and seven days after birth

\begin{tabular}{|c|c|c|c|c|c|c|c|c|}
\hline Group & Drug/dose & 2 days & & & & ays & & \\
\hline $\begin{array}{r}1 \\
2 \\
3 \\
6 \\
7 \\
8 \\
10 \\
11 \\
12\end{array}$ & $\begin{array}{l}\text { Buffer } \\
\text { Triac } 60 \mu \mathrm{g} \\
\text { Triac } 60 \mu \mathrm{g}+\text { verapamil } 1 \mathrm{mg} \\
\text { Verapamil } 4 \mathrm{mg} \\
\text { Buffer } \\
\text { Triac } 60 \mu \mathrm{g} \\
\text { Triac } 60 \mu \mathrm{g}+\mathrm{A} 2318730 \mu \mathrm{g} \\
\text { Triac } 60 \mu \mathrm{g}+\mathrm{A} 2318760 \mu \mathrm{g} \\
\text { A23187 } 60 \mu \mathrm{g}\end{array}$ & $\begin{array}{ll}1 & 1 \\
2 & 2 \\
0 & 0 \\
1 & 2 \\
0 & 1 \\
2 & 1 \\
2 & 2 \\
1 & 2 \\
2 & 1\end{array}$ & $\begin{array}{l}0 \\
1 \\
1 \\
2 \\
0 \\
3 \\
1 \\
1 \\
1\end{array}$ & $\begin{array}{lll}0 & 0 & \\
2 & & \\
1 & 0 & 1 \\
1 & & \\
2 & & \\
1 & & \\
1 & & \\
1 & & \end{array}$ & $\begin{array}{l}0 \\
1 \\
0 \\
2 \\
0 \\
1 \\
1 \\
2 \\
1\end{array}$ & $\begin{array}{l}1 \\
1 \\
1 \\
1 \\
0 \\
1 \\
1 \\
1 \\
1 \\
0\end{array}$ & $\begin{array}{l}0 \\
2 \\
0 \\
1 \\
2 \\
2 \\
0 \\
1\end{array}$ & $\begin{array}{l}0 \\
1 \\
0 \\
0 \\
1 \\
2 \\
1 \\
0\end{array}$ \\
\hline
\end{tabular}

^Scores for individual rats. 


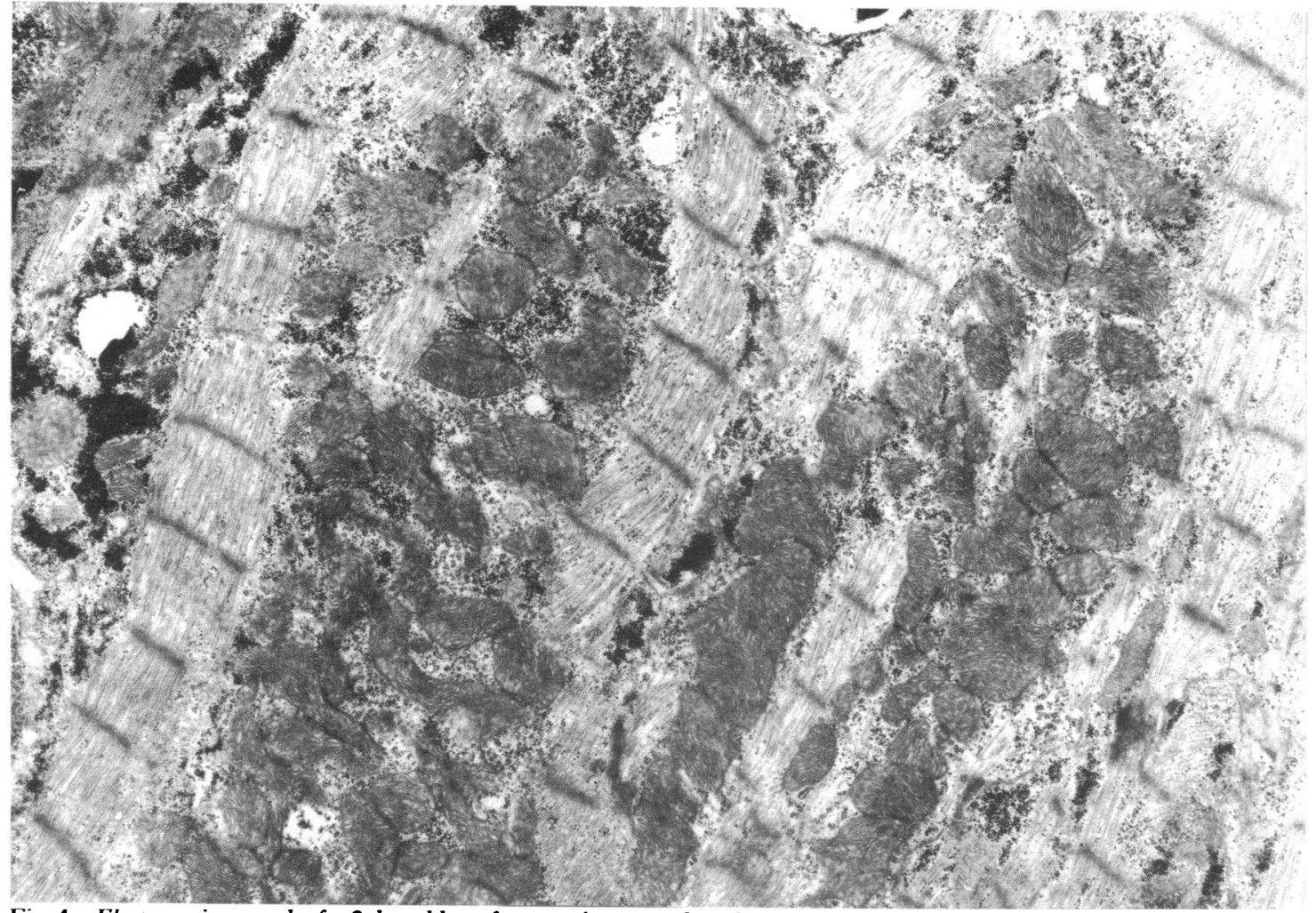

Fig. 4 Electronmicrograph of a 2 day old rat from a triac treated mother (group 2). The number of mitochondria separating parallel sarcomeres indicates that hypertrophy is present (compare with Fig. 1). (Lead citrate and uranyl acetate; original magnification $\times 12000$.)

with A23187 alone showed mild hypertrophy. The reason for the discrepancy in this case between the histological and electronmicroscopical findings is not known.

\section{Discussion}

In the experimental model described here some disarray was observed at histological level, but the most striking features were at the ultrastructural level. Disarray by itself must, however, be interpreted with caution. At one time it was considered to be pathognomonic of hypertrophic cardiomyopathy, ${ }^{13}$ but later reports from the same institute suggested that it is merely a feature of ordinary hypertrophy. ${ }^{14}$ More recent work has suggested that angulation of the block during section cutting can alter results and indicate the presence of disarray when there was none and vice versa. ${ }^{15}$ The question of the importance of disarray is still under discussion. ${ }^{16-18} \mathrm{~A}$ summary of the subject states that disarray, at both histological and electronmicroscopical levels, is indicative but not pathog- nomonic of hypertrophic cardiomyopathy, and additional features such as gross asymmetric hypertrophy of the left ventricle must also be present. ${ }^{19}$ The process of disarray must, however, start somewhere, and these events will first become evident at the electronmicroscopical level. Neither conclusive disarray at the histological level nor hypertrophy at the gross level has been produced by these experiments, but in view of the severity of the disarray at the electronmicroscopical level we consider it to mimic that seen in hypertrophic cardiomyopathy in man. Induction of disarray after administration of triac to pregnant rats is an ideal experimental model which lends itself to study of the pathogenesis of disarray, the fundamental morphological expression of hypertrophic cardiomyopathy.

Verapamil was first used in the treatment of hypertrophic cardiomyopathy in man because investigation of the hereditary cardiomyopathy of Syrian hamsters showed that calcium uptake and content were increased and that the metabolic and anatomical abnormalities could be prevented by the administration of verapamil, which blocks the inward calcium transport across cell membranes. ${ }^{20}$ 
It was hoped that verapamil would decrease the incidence of sudden death in human patients with hypertrophic cardiomopathy. Long term follow up now suggests that this aim has not been realised and verapamil has been succeeded by other drugs such as amiodarone. ${ }^{21}$ It is, however, still widely used clinically particularly because of its reported actions in reducing hypertrophy. ${ }^{9}$ It is therefore important to note the surprising finding that when the high dose of verapamil was given alone to pregnant rats it actually produced cardiac hypertrophy in the offspring.

The possible role of hyperthyroidism in the inception and development of hypertrophic cardiomyopathy is unknown. Previous experiments, in which triac was administered with DL or D propranolol, ${ }^{1011}$ timolol, or procainamide, ${ }^{7}$ have established that membrane stabilisation is the mechanism by which triac induced disarray is prevented. It was therefore suggested that the deleterious action of triac is to increase the permeability of the myocardial cell membrane, resulting in an influx of calcium ions.

The aim of the first experiment reported in this paper was to find out whether verapamil would prevent disarray and hypertrophy, and it was found that at the low dose both were reduced. It was therefore considered unnecessary to repeat the experiment to see if offspring were produced in the groups receiving triac and the higher doses of verapamil. The doses used were comparatively greater than those used in man, and it is possible that the insult was too great and eventually caused the death of one of the rats in the high dose group.

The role of calcium has further been established by the use of $\mathrm{A23187}$. This compound is a divalent cation specific ionophore that facilitates the passage of calcium across cell membranes, thus raising the level of intracellular calcium. When given alone this compound had the same effects as triac in producing disarray and hypertrophy. This may be a result of an increase in contractility of the developing cell. The heart in hypertrophic cardiomyopathy is in a hypercontractile state, and it is known that increases in myocardial cell calcium content enhance myocardial contractility. ${ }^{22}$ Furthermore, in heart muscle from hyperthyroid dogs and rabbits microsomes with enriched sarcoplasmic reticulum were found to accumulate and exchange calcium at increased rates. ${ }^{2324}$

Bearing in mind what has already been described, it is likely that, in some patients, hypertrophic cardiomyopathy may have a multifactorial background-for example, a heightened sensitivity to catecholamines or abnormal neural crest development. ${ }^{25}$ Although the association of hypertrophic cardiomyopathy with hyperthroidism, whether overt or covert, is rare, the effects of triac on developing rat hearts described above justify consideration of the following mechanism. Triac has a destabilising action on the cell membrane, resulting in an influx of calcium ions, which produces an isometric contraction such as that suggested by Bulkley et al. ${ }^{26}$ This may lead to disarray, which, once established, may be self-perpetuating.

The search for an animal model showing features of hypertrophic cardiomyopathy at all levels of investigation is continuing. Work so far has suggested that an endogenous mechanism is likely to be operating in some patients with hypertrophic cardiomyopathy, and this experimental model has contributed to the understanding of the pathogenetic pathway involved.

We thank Mr B Baker, Royal Free Hospital, for the preparation of solutions for injection and Abbott Laboratories Ltd for the supply of verapamil. We also thank Ciba Geigy Ltd for the financial support of these investigations.

\section{References}

1 WHO/ISFC. Report of the WHO/ISFC task force on the definition and classification of cardiomyopathies. $\mathrm{Br}$ Heart $\mathcal{F}$ 1980; 44: 672-73.

2 Maron BJ, Roberts WC. Quantitative analysis of cardiac muscle cell disorganization in the ventricular septum of patients with hypertrophic cardiomyopathy. Circulation 1979; 59: 689-706.

3 van Noorden S, Olsen EGJ, Pearse AGE. Hypertrophic obstructive cardiomyopathy, a histological, histochemical and ultrastructural study of biopsy material. Cardiovasc Res 1971; 5: 118-31.

4 Olsen EGJ, Symons C, Hawkey C. Effect of triac on the developing heart. Lancet 1977; ii: 221-3.

5 Symons C, Richardson PJ, Feizi O. Hypertrophic cardiomyopathy and hyperthyroidism: a report of three cases. Thorax 1974; 29: 713-9.

6 Bell R, Barber PV, Bray CL, Beton DC. Incidence of thyroid disease in cases of hypertrophic cardiomyopathy. Br Heart $\mathcal{F}$ 1978; 40: 1306-9.

7 Pearce PC, Hawkey CM, Symons C, Olsen EGJ. Myocardial disarray: the mode of action of triac, the acetic acid metabolite of triiodothyronine. Eur Heart $\mathcal{F} 1984 ; 5$ (suppl): 208.

8 Rosing DR, Kent KM, Borer JS, Seides SF, Maron BJ, Epstein SE. Verapamil therapy: a new approach to the pharmacologic treatment of hypertrophic cardiomyopathy. I. Hemodynamic effects. Circulation 1979; 60: 1201-7.

9 Kaltenbach M, Hopf R, Kober G, Bussmann WD, Keller M, Petersen Y. Treatment of hypertrophic obstructive cardiomyopathy with verapamil. Br Heart $\mathcal{F}$ 1979; 42: 35-42.

10 Hawkey CM, Olsen EGJ, Symons C. Production of 
cardiac muscle abnormalities in offspring of rats receiving triiodothyroacetic acid (triac) and the effect of beta adrenergic blockade. Cardiovasc Res 1981; 15: 196-250.

11 Pearce PC, Hawkey CM, Symons C, Olsen EGJ. Effect of triac and $\beta$-adrenergic blocking agents on the myocardium of developing rats. Cardiovasc Res 1983; 17: 7-14.

12 Venable J, Coggeshall R. A simplified lead citrate stain for use in electronmicroscopy. $\mathcal{F}$ Cell Biol 1965; 25: 407-8.

13 Ferrans VJ, Morrow AG, Roberts WC. Myocardial ultrastructure in idiopathic hypertrophic subaorticstenosis. A study of operatively excised left ventricular outflow tract muscle in fourteen patients. Circulation 1972; 45: 769-92.

14 Maron BJ, Ferrans VJ, White RI Jr. Unusual evolution of acquired infundibular stenosis in patients with ventricular septal defect. Circulation 1973; 48: 1092-103.

15 Becker AE, Caruso G. Myocardial disarray in a critical review. Br Heart $\mathcal{F}$ 1982; 47: 527-38.

16 Maron BJ. Myocardial disorganisation in hypertrophic cardiomyopathy. Another point of view. Br Heart $\mathcal{f}$ 1983; 50: 1-3.

17 Davies MJ. The current status of myocardial disarray in hypertrophic cardiomyopathy. Br Heart $\mathcal{f} 1984$; 51: 361-3.

18 Becker AE. Myocardial disorganisation in hypertrophic cardiomyopathy [Letter]. Br Heart $\mathcal{F} 1984$; 51: 466-8.

19 Olsen EGJ. Myocardial disarray revisited. $\mathrm{Br} \mathrm{Med} \mathcal{J}$
1982; 285: 991-2.

20 Lossnitzer K, Janke J, Hein B, Stauch M, Fleckenstein A. Disturbed myocardial calcium metabolism: a possible pathogenetic factor in the hereditary cardiomyopathy of the Syrian hamster. In: Fleckenstein A, Dona G, eds. Recent advances in studies on cardiac structure and metabolism, vol. 6, Pathophysiology and morphology of myocardial cell alteration. Baltimore: University Park Press, 1975: 207-17.

21 McKenna WJ, Harris L, Perez G, Krikler DM, Oakley C, Goodwin JF. Arrhythmia in hypertrophic cardiomyopathy. II: Comparison of amiodarone and verapamil in treatment. Br Heart $\mathcal{F} 1981$; 46: 173-8.

22 Nayler WG. Calcium exchange in cardiac muscle: a basic mechanism of drug action. Am Heart $\mathcal{F}$ 1967; 73: 379-94.

23 Nayler WG, Merrillees NCR, Chipperfield D, Kurtz JB. Influence of hyperthyroidism on the uptake and binding of calcium by cardiac microsomal fractions and on mitochondrial structure. Cardiovasc Res 1971; 5: 469-82.

24 Suko J. The calcium pump of sarcoplasmic reticulum: functional alterations at different levels of thyroid state in rabbits. $f$ Physiol (Lond) 1973; 228: 563-82.

25 Perloff JK. Pathogenesis of hypertrophic cardiomyopathy: hypotheses and speculations. Am Heart $\mathcal{f}$ 1981; 101: 219-26.

26 Bulkley BH, Weisfeldt ML, Hutchins GM. Isometric cardiac contraction. A possible cause of the disorganized myocardial pattern of idiopathic hypertrophic subaortic stenosis. N Engl f Med 1977; 296: 135-9. 